Nepalese Culture

Vol. XIV : 95-104, 2020

Central Department of NeHCA,

Tribhuvan University, Kathmandu, Nepal

DOI: https://doi.org/10.3126/nc.v14i0.354278

\title{
शक्तिका श्रोत नवदुर्गाहरू
}

\section{निर्मला पोखरेल}

उप प्राध्यापक, नेपाली इतिहास संस्कृति तथा पुरातत्व केन्द्रिय विभाग, त्रि.वि. E-mail : nirmala.pokharal33@gmail.com

\section{लेखसार}

मानव सभ्यता संग-संगै मातृशक्तिको उपासना पद्दतिको शुरुवात भएको देखिन्छ। यो समयमा प्रजननमा समर्थ नारीमा देवी शक्तिको कल्पना गरिन्थ्यो। मानवको यही भावनाले आदिकालमा नै शक्तिको रूप लियो। सिन्धु सभ्यतामा धरती मातालाई 'पृथिवीकी रानी' मानी शक्तिको रूपमा पूजा गर्दथे। देवताहरूको सर्वोच्च देवत्व शक्तिमा नै निहित भएको मानिन्छ। शक्ति सर्वव्यापी तत्व हो, त्री-देव लगायत सम्पूर्ण देवताहरू शक्तिको उपस्थिति विना क्रियाशील हुन सक्दैनन् । उनले देवीदेवता र प्राणीलाई जन्म दिई शक्तिको संचार गर्ने हुनाले स्त्रीरूपमा कल्पना गरियो र आमाको स्थान दिईयो र उनै विश्वशक्तिको नाम भगवती पनि रहन गयो। विस्तारै यीनै भगवतीका विभिन्न स्वरूपको उपासना गरिन थालियो यही कममा दुर्गाका रूपमा पनि उनको स्वतन्त्र अस्तित्व प्रारम्भ भयो। दुर्गास्वरूपमा पनि नवदुर्गा मण्डलीको छुटै समुह रहेको छ। नवदुर्गा समूहमा मुख्य देवी दुर्गा हुन् र यिनैका अन्य आठरूपलाई जोडेर नवदुर्गा हुने हुन्। सर्वशक्तिमान देवी महिषासुरमर्दिनी पनि नवदुर्गा भवानी हुन्। नवैवटी देवीहरूको स्वरूपमा नवदुर्गा गण संस्कृति सुस्पस्ट रूपमा भने अंशुवर्माको समय देखि धार्मिक मतहरूमा तन्त्र सिद्धान्तको वढ़ता प्रभाव पर्न थालेपछि देखिएको पाइन्छ ।

नवदुर्गा समूहमा गनिने दुर्गादेवीहरूको नाम नेपाल र भारत दुवै ठाउँमा फरक फरक देखिन्छ। उपत्यकामा नवदुर्गा संस्कृतिको ख्यातिप्राप्त स्थान भक्तपुर रहिआएको छ। यहाँ देहधारी मानवलाई नै नवदुर्गा वनाएर नृत्य, पूजाआजा आदि पनि गरिन्छ। आफुहरूले समाधान गर्न नसकेका समस्याहरू सल्टाजन, पराजित गर्न नसकेका दैत्यहरूलाई नष्टगर्न, आफुमा विशेष शक्ति आर्जन गर्न, देवताहरू पनि यिनै दुर्गा देवीहरूलाई आह्वान गरि पूजा-आराधना गर्दछन्। शक्तिका श्रोत नवदुर्गाहरू शीर्षकको यो लेखले समग्रमा नवदुर्गाको परिचय, प्राचीनता, विकाशको चर्चा गरेको छ साथै अरु उपशीर्षकहरूमा यिनै देवीहरूको विषयवस्तुमा केन्द्रित भएर विभिन्न सन्दर्भहरूको विष्लेषण सहित निष्कर्ष प्रस्तुत गरिएको छ।

शब्द कुज्जि : मातृशक्ति, नवदुर्गा, भगवती, महिषासुरमर्दिनी 


\section{परिचय}

शाक्त सम्प्रदायमा विश्वव्रह्माण्डको एकमात्र परम कारण देवी या महाशक्तिलाई मान्दे उनलाई नित्य, शाश्वत तत्वका रूपमा उपासना गरिन्छ। मातृशक्तिको उपासना परम्परा ज्यादै प्राचीन हो । जे.प्रिस्टनको मतमा देवीपूजाको प्रमाण तीसहजार वर्षपूर्व नवपाषाणकालमा नै पाइन्छ, (प्रिस्टन, १९६० पृ. ६)। त्यसैगरी मध्य तथा पूर्वी यूरोपमा प्राप्त हात्तीका दाँत तथा हाडवाट वनेका नारी आकृतिका अवषेशहरू वीस हजार वर्ष भन्दा पुराना पूर्वपाषाणकालीन हुन् र त्यही समय देखि नै देवी पूजाको प्रचलन रहेको प्रमाण पाइन्छ। समाजशास्त्री तथा पुरातत्वविद्हरू अनुसार परिवार तथा समाजको आविर्भाव एवं प्रारम्भिक गठनमा आमाको रूपमा नारीले महत्त्वपूर्ण भूमिका निर्वाहा गरेकाले विश्वका विभिन्न भागमा मातृसत्तालाई महत्त्वपूर्ण शक्तिकोरूपमा लिईएको र यसैको परिणामस्वरूप मातृशक्तिकोरूपमा देवीपूजाको प्रचलन प्रारम्भ भएको मानिन्छ। केनोपनिषदमा उल्लेख भएको उमा हैमावती, दुर्गा अर्थात पार्वतीको दोश्रो नाम हो (श्रीवास्तव, १९९० पृ. १२९)। प्राचीन धर्मग्रन्थहरूमा मानवतामाथि परेको कष्ट, आपत र सझ्टको क्षणमा शक्तिको आराधना र अनुकम्पाबाट कष्ट निवारण भएको उल्लेख पाइन्छ। कुनै पनि प्राणीमा कुनै कार्य, ज्ञान, कर्म सम्पन्न गर्नको निमित्त त्यसमा रहने सामर्थ्य नै शक्ति हो। विना शक्ति कुनै पनि कार्य गर्न असंभव छ। त्यसैले कुनै कार्य गर्न नसकिने भएमा 'सक्तिन' अर्थात ' शक्ति + न'=शक्ति छैन भनिन्छ ।

शक्ति वस्तुतः एउटै छ, अद्वितीय छ, तर आफू एउटै भएर पनि भिन्नभिन्न कार्य गर्ने गराउने अलग अलग शक्तिका रूपमा प्रकाशित हुन्छ र प्राणीका सवै कार्य सम्पन्न हुन्छन् (उपाध्याय, वि. सं.२०७४ पृ. १)। ‘शक्तिकागमसर्वस्व' अनुसार शिव स्वयं आफूलाई शक्तिले गर्दा अथवा शक्ति भएर नै म शिव भएको हूँ, शक्ति विना म शव मात्र हूँ भन्दछन् । स्वयं शंकराचार्य सौन्दर्यलहरीको पहिलो श्लोकमा नै 'शक्ति भएर शिव शिव भएका हुन्, शक्ति विना शिव शवस्वरूप नै हुन्, स्पन्दन पनि गर्न सक्देनन् भनेर शक्तिको उत्कर्ष प्रतिपादन गर्दछन् (उही)।

यही शक्तिका बिबिध स्वरूपहरू मध्ये दुर्गा एक हो र यो स्वरूपको पनि अरु हजारौं स्वरूपहरू रहेका छन् । भगवती देवी सर्वव्यापक एकात्मक शक्ति भएपनि उनका विभिन्न स्वरूपहरू उपासनाका लागि प्रयुक्त हुन्छन्। ती मध्ये पनि नवदुर्गाका स्वरूप अत्यन्तै पवित्र मानिन्छन् । दुर्गाहरूका नामहरू भने ठाउँ, समय, स्थान अनुरूप फरक- फरक रहेका छन्।

\section{अध्ययन विधि}

यो अनुसन्धान सम्पन्न गर्नका लागि गुणात्मक शोध पद्धति अपनाउँदै प्राथमिक र द्वितीयक श्रोतहरु प्रयोग गरिएका छन् । जसअन्तर्गत प्राथमिक श्रोतहरुमा प्रत्यक्ष अवलोकन, सम्वन्धित विद्वाव वर्गहरू लगायत पुजारी, भक्तजन जस्ता व्यक्तित्वहरूसँग अन्तर्वार्ता लिने कार्य गरिएको छ। द्वितीयक श्रोतहरूमा विभिन्न पत्रपत्रिका, पुस्तक, विद्वानवर्गको लेख रचनाहरूबाट तथ्य संकलन गरिएको छ। प्राप्त हुन आएका दुबै थरी श्रो तहरुका तथ्यलाई वणनात्मक शैलीमा प्रस्तुत गरि आलेख तयार पारिएको छ। 


\section{उपत्यका भित्रका केही प्रशिद्ध देवीमन्दिरहरूू}

भक्तपुर- व्रह्मायणी (जगत्प्रकाश मल्लका पालामा निर्मित), ईन्द्रायणी (सत्रौ शताव्दिमा निर्मित), न्यातपोल सिद्धिलक्ष्मी (महिषासुरमर्दिनी) (भुपतिन्द्र मल्लले ने.सं. इ२६ मा निर्माण, तौमडी टोल); सिद्धिलक्ष्मी (जगत प्रकाश मल्लद्वारा निर्मित, पचपन्नफयाले दरवार छेउ), चामुण्डा (वि.सं.१७४२ मा निर्मित), कुमारी, नवदुर्गा, तलेजु आदि रहेका छन्।

पाटन- वाराही (वि.सं.१७४२, वोडे), महालक्ष्मी (थसिखेल, वीरनारायणले वि.सं. १७४६दमा निर्माण), वगलामुखी, तलेजु, वज्रवाराही, टोलटोलमा रहेका दशमहाविद्याहरू आदि रहेका छन्।

काठमाण्डु- कुमारी (जीवित देवी), तलेजु, नक्साल भगवती, शोभाभगवती, ईन्द्रायणी (विष्णुमती नदी छे, ), मैतीदेवी, कालीका देवी, भद्रकाली, शंकटा, अन्नपूर्णा, नरदेवी, रक्तकाली, श्वेतकाली, वैष्णवी (कीर्तिपुर र पाँगाका), कलंकीमाई (कलंकी), महालक्ष्मी (थानकोट) आदि रहेका छन्।

यी वाहेक दक्षिणकाली, वज्रयोगिनी (साँखु), छिन्नमस्ता (चाँगु), छिन्नमस्ता मन्दिर भित्रको छिन्नमस्ता मूर्तिको वायाँ पट्टि ई. तेस्रो शताव्दिताकाको महिषासुरमर्दिनीको मूर्ति रहेको छ, जसलाई पुजारीवर्ग र भक्तहरूले 'महालक्ष्मी/संकटा' कोरूपमा मान्दै आएका छन् (श्रेष्ठ, वि.सं.२०७४ पृ. ६९) । ईन्द्रायणी (चाँगुनारायण मन्दिरवाट करीव ३० मिनेट उत्तर), नाला भगवती, चण्डेश्वरी (वनेपा र टोखाका) आदि देवीहरूको उत्तिकै प्रशिद्धी रहेको छ।

दुर्गा : केनोपनिषदमा उमा, हैमावतीको उल्लेखित आउँछ जुन दुर्गा अर्थात पार्वतीको दोश्रो नाम हो र सांख्यायन श्रौतसूत्रमा दुर्गांको कल्पना रुद्रकी पत्नीको रूपमा गरिएको छ भने बौधायन धर्मसूत्रमा दुर्गालाई अम्बा, आर्या भगवती, महाबैष्णवी, महाकाली पनि भनिएको छ (श्रीवास्तव, १९९० पृ. १२९) । गृह्यसूत्र कालसम्ममा दुर्गाका सौम्य रूप र घोर रूपको जन्म भैसकेको कुरा महाभारतको दुर्गास्तोत्रबाट पुष्टी हुन्छ, (उही)। कर्मको आधारमा पनि देवीको दुर्गा नाम रहन गएको छ। स्कन्द पुराण अनुसार एक समय रुरु दैत्यका पुत्र दुर्गमन (दुर्ग) नामका महादैत्यले देवताहरूलाई ज्यादै दुख दिएकाले शिवजीले उक्त असुरलाई मार्नकालागि देवीलाई अनुरोध गरे र ठूलो संग्राम पछि, देवीको हातबाट दुर्ग मारियो, जसका कारण उनी दुर्गा नामले प्रशिद्ध भईन् (जोशी, वि.सं. २०७० पृ. ४२३)।

दुर्गाको प्रतिमा लक्षण : दुर्गाका पनि विविध स्वरूपहरू रहेका छन् अष्टभुजी, दशभुजी, षोडशभुजी, अष्टादशभुजी, योगेश्वरी आदि। विष्णुधर्मोत्तर पुराण अनुसार सिंहमा आसीन आठवाहुहरू भएकी, वाहुहरूमा वाण, शूल, खड्ग, चक्र, चन्द्रबिम्व, कपालपात्रआदि धारण गरेकी दुर्गाको उल्लेख छ। सुप्रभेदागम् ग्रन्थ अनुसार दुर्गाको आठवाहुहरू हुने र वाहुहरूमा शंख, चक्र, धनुष, वाण, खड्ग, खेटक, शूल तथा पात्र रहने उल्लेख छ (श्रीवास्तव, १९९० पृ. १३१)। दुर्गाले वाहुहरूमा धारण गरेका आयुधहरूका अर्थहरू यसप्रकार रहेका छन् - शंखको अर्थ प्रतिध्वनी; चक्रको अर्थ रक्षा, संसार चक्र; वाणको अर्थ पापमोचकता; पात्रको अर्थ पोषणको प्रतिक; खड्गको अर्थ दायाँमा भए सिद्धि र मारण वायाँमा भए ज्ञानको प्रतिक मानिन्छ, (जवरा, २०२० पृ. च, छ)। 
सप्त, अष्टमातृकाहरूले आ-आफ्ना पुरुष देवताहरूले धारण गर्ने आयुध र वाहन ग्रहण गरेका हुन्छन्। कहिलेकाँही यिनीहरूलाई पनि नवदुर्गागणमा सामेल गरिन्छ।

\section{नवदुर्गाहरू}

हिन्दु शाक्त परंपरामा नवदुर्गा सम्प्रदायको ठूलो महत्त्व छ, यिनीहरू दानवरूपी शक्तिलाई विनाश गर्ने सामुहिक रूपमा पूजिने नौवटी देवीहरूको संयुक्त समूह हो। आफुहरूले समाधान गर्न नसकेका समस्याहरू सल्टाउन, पराजित गर्न नसकेका दैत्यहरूलाई नष्टगर्न, आफुहरूमा विशेष शक्ति आर्जन गर्न, देवताहरू पनि यिनै दुर्गा देवीहरूलाई आह्वान गरि पूजा-आराधना गर्दछ् (पोखरेल, वि.सं.२०७७ पू. ७)। नवैवटी देवीहरूको स्वरूपमा नवदुर्गा गण संस्कृति सुस्पस्ट रूपमा अंशुवर्माको समय देखि धार्मिक मतहरूमा तन्त्र शिद्धान्तको वढ्ता प्रभाव पर्न थालेपछि, देखिएको पाइन्छ, (श्रेष्ठ, वि.सं. २०७४ पृ. ७०)।

वैदिक धर्ममा $\curlyvee$ रात्री प्रमुख छन् - मोहरात्री, सुखरात्री, शिवरात्री, कालरात्री । यी मध्ये कालरात्री नवदुर्गाहरू पुजिने रात्री हुन्। रात्री भनेको देवता हो र यो सोमतत्वको प्रतिक पनि हो; सोमतत्वले प्रकृति वा शक्ति भन्ने वुभाउँछ र कालरात्रीमा पुजिने शक्तिचाहिँ नवदुर्गाहरू हुन्।

भगवती देवी सर्वव्यापक एकात्मक शक्ति भएपनि उहाँका विभिन्न स्वरूपहरू उपासनाका लागि प्रयुक्त हुन्छन्। ती मध्ये पनि नवदुर्गाका स्वरूप अत्यन्तै पवित्र मानिन्छन्। शिवपुराणमा शिवद्वारा पुत्र गणेशको शिरोच्छेदन गरिंदा देवी पार्वती अत्यन्त ऋुद्ध भई आफ्नै शरीरबाट शिव लगायत सम्पूर्ण देवताहरूको संहार गर्ने हेतु लाखौ शक्ति (देवी)हरूको सृष्टि गरेकी थिइन् र तीनीहरूमध्ये नवदुर्गा प्रमुख मानिन्छन्। यी नवदुर्गाहरूले चारै दिशाबाट देवताहरूलाई त्राहिमाम् पारे पश्चात देवताहरूले नवरात्रको अवसरमा ऋमश: यीनै नवदुर्गाहरूको पुजा आरधना गरेपछि दुर्गाहरू शान्त भएको चर्चा पाइन्छ (जोशी, वि.सं. २०७० पृ. ३९६)। प्राचीन समयमा नवरात्रमा नै विजयादशमीका दिन राजाहरू अपराजिता दुर्गाको पूजागरी आफ्नो राज्यको दशै दिशाको सीमा बढाउन अभियान आरम्भ गर्दथे (उही) ।

दुर्गाका नामहरू जन्मार्थक र कर्मार्थक अर्थात जन्म र कर्मका आधारवाट प्रसिद्ध रहेका छन् । यी नामहरू ठाउँ, समय, स्थान अनुरूप फरक-फरक पाइन्छन्। भारतीय क्षेत्रमा र नेपाली क्षेत्रमा पाइने नवदुर्गाका नामहरूमा निकै विविधता रहेको छ। भारतमा नवर्र्गाका रूपमा पुजाआजा हुने दुर्गाहरूमा सप्तमातृकाहरू (व्रम्हायणी, माहेश्वरी, कुमारी, वैष्णवी, वाराही, ईन्द्रायणी, चामुण्डा) मा काली र महिषासुरमर्दिनीलाई थपेर लिईन्छ। भारतमा नै पनि बंगाल र असाम क्षेत्रमा नवदुर्गाका सूचीमा सप्तमातृकाहरूका साथमा 'चण्डी' र ' कामाख्या' राखिन्छ। दक्षिण भारतमा नवदुर्गाको एक रूपमा भद्रकालीलाई पनि लिइन्छ भने राजस्थान, उडिसा, मध्यप्रदेश तिर नवदुर्गांका रूपमा 'सप्तमातृका' ‘काली र 'दुर्गा'लाई लिईन्छ (पोखरेल, वि.सं.२०७७ पृ.७) ।

नेपाल भित्रै पनि भक्तपुर र काठमाण्डौमा नवदुर्गाको समुहका नामहरू फरक- फरक रहेको छन् । हाल भक्तपुरमा नवदुर्गा गणमा (नृत्यको अवसरमा) व्रम्हायणी, माहेश्वरी, कुमारी, वैष्णवी, वाराही, ईन्द्रायणी, महाकाली, महालक्ष्मी र त्रिपुरासुन्दरीलाई लिईन्छ। भक्तपुरमा राजा आनन्ददेव (वि.सं.१२०४-१२२४)ले राजधानी वसाउँदा तान्त्रिक सुरक्षा हेतु राजधानी नगरलाई यन्त्राकाररूपमा नगर भित्र र वाहिर आठ स्थानमा 
अष्ठमातृकाका पीठ एवं देवगृह लगायत नगरको मध्यभागमा त्रिपुरासुन्दरीको देवगृह समेत प्रतिष्ठापित गरे, यहाँ अष्ठमातृका गणकी अधिष्ठात्री देवी त्रिपुरासुन्दरी हुन्, अष्ठमातृका गणमा त्रिपुरासुन्दरी समाविष्ट भएपछि आविर्भाव हुने एकिकृतरूप नवदुर्गा हो (श्रेष्ठ, वि.सं.२०७४ पृ. ७०)। यसरी उनले सिड्गो शहरलाई यन्त्राकार एवं नवदुर्गामय वनाई नयाँ राजदरवारको नाम 'त्रिपुर' राखे। जुन मध्यकालीन नेपाल मण्डलको पहिलो दरवार हो (श्रेष्ठ, वि.सं. २०७४ पृ.७०)।

ब्रम्हवैवर्त्तपुराणको प्रकृतिखण्डमा भगवान् विष्णुले नारद ऋषिलाई ब्रम्हाण्ड-मोहन नामक प्रकृतिकवचमा नव-दिगदुर्गाहरूले आ-आफ्नो दिशामा रहेर वरिपरिबाट रक्षा गरिरहेका हुन्छन् भन्दै ती अधिष्ठात्री देवीहरूको नाम यसप्रकार वताएका छन् :-

१). प्रकृति- पूर्व २). चण्डिका- आग्नेयकोण ३). भद्रकाली- दक्षिण ४). महेश्वरी- नैऋत्यकोण ४). वाराही- पश्चिम ६). सर्वमड़ला- वायव्यकोण ७). बैष्णवी- उत्तर द). शिवप्रिया- ईशानकोण ९). जगदम्बिकाजल, थल र आकाश (जोशी, वि.सं. २०७० पृ. ४२४)।

अपराजितपृच्छा नामक ग्रन्थमा नवदुर्गाका रूपमा महालक्ष्मी, नन्दा, क्षेमझकरी, शिवदूती, महाचण्डा, भ्रमरी, सर्वमड़ला, रेवती, हरसिद्धिलाई प्रस्तुत गरिएको छ। आगमग्रन्थ अनुसार नवदुर्गामा निलकण्ठी, क्षेमड़करी, हरसिद्धि, रुद्रांश-दुर्गा, वन-दुर्गा, अग्नी-दुर्गा, जप-दुर्गा, विन्ध्यवासिनी-दुर्गा, रिपुमारि-दुर्गा पर्दछन् (श्रीवास्तव, १९९० पृ. १३०)। पुराणमा नवदुर्गाका रूपमा रुद्रचण्डा, प्रचण्डा, चण्डोग्रा, चण्डनायिका, चण्डा, चण्डवती, चण्डरूपा, अतिचण्डिका र उग्रचण्डिकालाई लिईएको छ (उही)। मार्कण्डेय पुराणको देवी महात्म्यमा काल्पनिक आयुको आधारमा दुर्गाहरूको नामाकरण यसरी गरिएको छ :- एक वर्षकी वालिकाको रूपमा सन्ध्या, दुई वर्षकी सरस्वती, सात वर्षकी चण्डिका, आठ वर्षकी शाम्भवी, नौ वर्षकी दुर्गा, दशकी गौरी, तेह्रकी महालक्ष्मी, सोह्रकी ललिता हुन् (उही पृ. १२९)।

दशैंको नवरात्रीमा गरिने दुर्गापूजामा २ वर्षदेखि १२ वर्षभित्रका ९ कन्याहरूलाई ९ दिनसम्म दुर्गाका रूपमा पूजागर्ने परम्परा रहेको छ पहिलो दिनदेखि कमश: पुजा गरिने यिनीहरूको नाम यसप्रकार छन्- कुमारीत्रिमुर्ति- कल्याणी- रोहिणी- कालिका- चण्डिका- शाम्भवी- दुर्गा र सुभद्रा (पोखरेल, वि.सं.२०७७ पृ. ७)।

देवीभागवतमा उल्लेख भए अनुसार ईन्द्र, शिव, विष्णु एवं रामले कमश: वृत्तासुर, त्रिपुरासुर, मधुकैटभ तथा रावणलाई नष्ट गर्नका लागि नवरात्रभरी दुर्गाको व्रत गरेका थिए। चार ऋतुलाई मुख्य ऋतु मानेर बसन्तत्ततुमा चैत्र महिनाको चैतेदसैं, गृष्मत्रतुको दसैं आषाढमा, शरदऋतुको शारदीय दसैं आश्विनमा, शिशिरत्रतुको दसैं पौष महिनामा मानिन्थ्यो । संभवतः ईन्द्र, शिव, विष्णु एवं रामले लिएका नवरात्रब्रत यी उल्लेखित चार भिन्न-भिन्न ऋतुमा सम्पादित भएका थिए (पोखरेल, वि.सं.२०७७ पृ. ७)। यी चारैवटा ऋतुमा मनाईने दसैंको मुख्य नायिका महामाया भगवती दुर्गा हुन् र तिनैका विविध स्वरूपहरूले दुष्टताका प्रतिकका रूपमा रहेका दानवहरूलाई नष्ट गर्दछ् । उदाहरणस्वरूप भगवान् शिवको अनुरोधमा भगवतीले रुरु का पुत्र दुर्ग नामक महादैत्यलाई भयड़र युद्ध पश्चात नष्ट गरिदिन्छिन् र उनको यो स्वरूपलाई दुर्गा मानिन्छ। ब्रम्हाको प्रार्थनाबाट मधु र कैटभ नामक वलबान् महादानवहरूलाई नष्ट गरेपछिको दुर्गाको स्वरूपलाई महाकाली भनिन्छ। तेत्तीसैकोटी देवताहरूले प्रार्थना गरेपश्चात उनिहरूको कोधरूपी तेजबाट उत्पन्न भएकी दुर्गाले महिषासुर 
नामक महादैत्यलाई नष्ट गरेपश्चात उनको यो स्वरूप महालक्ष्मी (महिषासुरमर्दिनी) नामले प्रशिद्ध रह्यो । त्यस्तै देवताहरू कै प्रार्थनामा सबै देवगण र तीनै लोकको कल्याणको लागि गौरी देवीको शरीरबाट उत्पत्ति भई शुम्भ, निशुम्भ र धुम्रलोचन जस्ता महादैत्यहरूलाई नष्ट गरेकी दुर्गा (देवी) को स्वरूपलाई महासरस्वती, साथै शुम्भ- निशुम्भलाई मारेर भक्षण गर्दा ती दैत्यको रगतले शरीरका सबै अङ्र रक्तमय भएको हुनाले उनको यो स्वरूप रक्त-चामुण्डा नामले प्रशिद्ध रहेको छ (श्रीवास्तव, १९९० पृ. १३०)। उनको चण्ड र मुण्ड नामक दैत्यहरूलाई नष्ट गर्ने स्वरूपलाई चामुण्डा भनिन्छ। चराचर जगतको सृष्टिलाई निरन्तरता दिन महाकालीले संहार, महालक्ष्मीले जगतको पालन र महासरस्वतीले जगतको उत्पत्ति तथा ज्ञानको सन्चार गर्ने कार्यपनि सँगसँगै गरिरहेका हुन्छन् (पोखरेल, वि.सं. २०७७ पृ. ७)।

दुर्गासप्तशतीमा नवदुर्गालाई यसप्रकार चित्रित गरिएको छ -'प्रेतमा चढेकी देवी चामुण्डा, राँगोमा चढ्ने वाराही, ऐरावत हात्तीमा सवार गर्ने इन्द्राणी, गरुड वाहान हुने वैष्णवी, साँढेमा चढेकी माहेश्वरी, मयूर वाहन हुने कौमारी, हातमा कमलको फूल लिएर कमलमा वसेकी विष्णुप्रिया लक्ष्मी, श्वेतवर्ण र साँढे वाहन भएकी ईश्वरी, अनेक आभूषण धारण गरेकी हंसमा वसेकी ब्राहमी; यी नवदुर्गा देवीहरू समस्त योगले सम्पन्न छन्' भनी भनिएको छ (वसिष्ठ, वि.सं. २०४७ पृ. ४७-४६) र यही पुस्तकमा यी वाहेक अरु पनि अनेक देवीहरूको उल्लेख गरिएको छ र यसो भनिएको छ- ‘विविध आभूषणहरूको शोभालेयुक्त तथा नाना प्रकारका रत्नले सुशोभित, रथमा चढेका, कोधले चुर्मुरिएका शड्ख, चक्र, गदा, शक्ति, हलो, मुसल, खेटक, तोमर, परशु, पाश, कुन्त, त्रिशूल र उत्तम शाड्र्गधनुष आफ्ना वाहुहरूमा धारण गरेका यी दुर्गाहरूको उदेश्य शस्तहरूले दैत्यगणको नाश गर्नु र भक्तहरूलाई अभय दिई देवताहरूको कल्याण गर्नु हो' (वसिष्ठ, वि.सं. २०४५७ पृ. ४९-४००)।

कुनै एक समयमा मार्कण्डेय ऋषिले ब्रह्माजीलाई यो संसारमा अत्यन्त गोपनीय र मनुष्यको सबै प्रकारले रक्षागर्ने, हजुरले आजसम्म कसैलाई प्रकट नगरेको कुनै साधन मलाई भन्नुहोस् भनी अनुरोध गर्दा ब्रह्माजीले यस्तो साधन केवल देवी कवच नै हो भने । यो अत्यन्त गोपनीय, पवित्र र सबै प्राणीको उपकार गर्ने प्रकृतिको छ। यसमा देवीका नौ मूर्ति छन् तिनीहरूलाई नवदुर्गा भन्दछन् र तिनीहरूको नाम शेलपुत्री, ब्रह्मचारिणी, चन्द्रघण्टा, कुष्माण्डा, स्कन्दमाता, कात्यायनी, कालरात्री, महागौरी र सिद्धिदात्री हुन् । दुर्गा कवच पाठगरी दुर्गाहरूको स्तुती गर्नाले अगिनमा डढ्न लागदा, युद्धमा शत्रुले कष्टदिएमा, अगमस्थानमा पुगदा, भयले शरणागत भएका दुखीजनहरूलाई अबश्य रक्षा गर्ने छ भनी ब्रह्माजीले भनेको वचन परेको छ (वसिष्ठ, वि.सं. २०४७ पृ. ४५-૪६)।

तन्त्रप्रधान नवदुर्गागणको मूल चरित्र र गुप्तरूप महिषासुरमर्दिनी दुर्गाभवानी हो। नवदुर्गागणको जन्म, जीवन र मरणको मूल श्रोत भने तलेजु भवानी हो र गुप्तरूपमा उपासित रहिआएकी तलेजु भवानीको मूलरूप महिषासुरमार्दिनी दुर्गाभवानी हो (श्रेष्ठ, वि.सं. २०७४ पृ. ७१)।

यस प्रकार नवदुर्गा समुहभित्र विविध देवीका नामहरू समावेश भएका छन् । दुर्गा-सप्तशती लगायत पुराणहरूमा नवदुर्गा समुहमा शैलपुत्री, ब्रह्मचारिणी, चन्द्रघण्टा, कुष्माण्डा, स्कन्दमाता, कात्यायनी, कालरात्री, महागौरी, शिद्धमाता वा सिद्धिदात्री पर्दछन् । दुर्गा-सप्तशतीमा ब्रह्माजीले मार्कण्डेय ऋषिलाई यी नौ नामले प्रसिद्ध नवदुर्गा देवीहरू छन् भनी वताएका छन् (वसिष्ठ, वि.सं. २०४७ पृ. ४५)। 
"प्रथमं शैलपुत्री च द्वितीयं ब्रह्मचारिणी ।

तृतीयं चन्द्रघण्टेति कूष्माण्डेति चतुर्थकम् ॥ ३॥

पन्चमं स्कन्दमातेति षष्ठ कात्यायनीति च ।

सप्तमं कालरात्रीति महागौरीति चाष्टमम् ॥ $४$ ॥

नवमं सिद्धिदात्री च नवदुर्गा: प्रकीर्तिता:।

उक्तान्येतानि नामानि ब्रह्मणैव महात्मना ॥ $y$ ॥ (वसिष्ठ, वि.सं. २०४७ पृ. ४४-४६)।

क) शैलपुत्री : संस्कृतमा शैलको अर्थ पर्वत हो। पर्वतराज हिमालयकी पुत्रीका रूपमा उनलाई शैलपुत्री भनिएको हो। ख) ब्रह्मचारिणी : संसारका मुमुक्ष प्राणीहरूलाई सच्चिदानन्द रूप ब्रह्मको बोध गराउनका लागि निरन्तर लागिरहने हुनाले उनलाई ब्रह्मचारिणी भनिएको हो। ग) चन्द्रघण्टा : यिनले हातमा चन्द्रमाको आधार भएको घण्टा लिने हुनाले यिनको नाम चन्द्रघण्टा रहन गएको हो। घ) कुष्माण्डा : आध्यात्मिक, आधिभौतिक र आधिदैविक यी तीन तापहरूलाई कुष्मा भनिन्छ। आप्ना शरणमा आएका भक्तहरूको यी तापहरूलाई हरण गरिदिने हुनाले यिनलाई कुष्माण्डा भनिएको हो र यिनले पेटमा तापयुक्त संसार धारण गरेको हुन्छ। ङ) स्कन्दमाता : पार्वतीको इच्छा अनुसार सनत्कुमारले पार्वतीबाट जन्म ग्रहण गरेकोले उनको नाम स्कन्दमाता रहन गएको हो। यहाँ स्कन्द शब्दको अर्थ कार्तिकेय नभई सनत्कुमार हो भन्ने बुकनुपर्दछ। च) कात्यायनी : कुनै एक समयमा देवताहरूको कार्यसम्पादन खातीर भगवती देवीले कात्यायन ऋषिका आश्रममा अत्यन्त सुन्दर कुमारीका रूपमा अवतार लिनुभयो। देवीको बाल सौन्दर्यबाट मुग्धभएर कात्यायन ऋषिले पुत्रीको रूपमा स्वीकार गरेको हुनाले कात्यायनी नाम रहन गएको मानिन्छ। छ) कालरात्री : सम्पूर्ण प्राणीमात्रलाई कालले नष्ट गर्दछ, र काललाइ पनि नष्ट गर्ने देवीको उक्त स्वरूपलाई कालरात्री भनिएको हो। कालरात्रीको अर्थ विनासकारी पनि हुन्छ, यिनले सवै राक्षसहरूको विनाश गरेकोले पनि कालरात्री भनिएको हो। ज) महागौरी : यी देवीको रंग कालो वर्णको भएकोले शिवले एकदिन ख्यालठट्टामा ‘काली' भन्ने शव्द प्रयोग गरेछन्। यो शब्द उनलाईलाई मन परेन र अत्यन्त कठोर तपश्यागरी गोरो वर्ण प्राप्त गरेकीले, उनलाई महागौरी भनिएको मानिन्छ। क) सिद्धिदात्री : सम्पूर्ण मुमुक्षुहरू (प्राणीहरू) लाई मोक्ष प्रदान गर्ने हुनाले उनलाई सिद्धिदात्री भनिएको हो । सिद्ध, गन्धर्व, यक्ष, सुर- असुरहरुद्धारा सेवित भएकोले यिनलाई सिद्धिदायिनी पनि भनिन्छ।

माथि उल्लेखित नामहरू स्वयं ब्रहम्माजीले मार्कण्डेय ऋषिलाई बताउँदै (वसिष्ठ, वि.सं. २०४७ पृ. ४४-४५) यीनै नामहरू स्मरण गर्नाले मनुष्य जुनसुकै कष्ट र संकटमा परेको भएता पनि तत्कालै कष्ट र संकटबाट सजिलै छुट्न सक्तछ भन्ने उल्लेख छ (उही)। नेपालको सन्दर्भमा विशेष गरि नवदुर्गा समूहमा माथि उल्लेखित नवदेवीहरू शेलपुत्री देखि सिद्धिदात्री सम्मलाई नै लिने गरिन्छ। दशैंको अवसरमा नौदिन सम्म पुजिने नवदुर्गामा यी देवीहरूको प्रत्येक दिन ऋमश: पुजा हुन्छ।

नेपालमा अष्टमातृकाहरूमा त्रिपुरासुन्दरीलाई थपेर नवदुर्गा मानिएको पनि पाइन्छ र नवदुर्गा अन्तर्गत कहिले महिषासुरमर्दिनी, वत्सलादेवी, जयवागेश्वरी र गुह्येश्वरीलाई समेत राखेर पूजा उपासना गरिन्छ (एलेन, १९७४ प्. ४५-४५०)। 
काठमाडौ उपत्यकामा मध्यकालमा अष्टमातृकाहरूमै त्रिपुरासुन्दरीलाई गाभेर नवदुर्गा मानी नवग्रह शान्ति, युद्धमा विजय, माहामारी र प्रकोपहरूबाट बाँच्नका लागि पूजा गर्ने प्रचलन थियो र शक्ति पूजामा वलीप्रथा पनि शसक्त पाइएको छ। यहाँ वलीको अर्थ काम, कोध, लोभ, मोह, मद र मात्सर्य माथि विजय प्राप्त गर्नु हो र देवी दुर्गाको पाउमा आफ्ना काम, कोध, लोभ, मोह, अहंकार वासनाको अनन्त विस्तारलाई अर्पित गरी संयमित हुनसक्ने शकि बलिदानबाट मिल्ने विश्वास लिइन्छ। नवदुर्गालाई सामुहिकस्वरूप बाहेक अलग-अलगरूपमा पनि पूजा गर्ने परम्परा छ। भक्तपुरको गछेंटोलको नवदुर्गालाई सामूहिक स्वरूप बाहेक फरक शक्तिको रूपमा मानिन्छ। कोजाग्रत पूर्णिमाको दिन गद्दिनसीन राजाले यहाँ दर्शन गर्ने परम्परा राजतन्त्र हुन्जेल रहेको थियो। अर्थात नेपालमा ठूला शाकि पीठमध्ये यो पनि एक हो। किवंदन्ती अनुसार रायमल्लका छोराले नवदुर्गा मध्यरातमा नाचिरहेको देखेपछि, भक्तपुरमा नवदुर्गा नाच नचाउने परम्परा चलाएको मानिन्छ साथै यहाँको नवदुर्गा नाच रणजित मल्लले जगाएको भन्ने भनाइ पनि छ।

जयदेवको आठौ शताब्दीको च्यासलटोल पाटनको अभिलेखमा दशमीगोष्ठी उल्लेख भएको छ। धनवज्र वज्राचार्य अनुसार यसै समयदेखि नै दशमीपूजा (दिशी पूजा/दुर्गा पूजा) अर्थात दुर्गा पुजा गरी दशैं चाडको प्रचलन नेपालमा भएको हुनुपई (वज्राचार्य, वि.सं. २०५३ पृ. २१२)। बाह्रौ शताब्दी ताकाका राजा गुणकामदेवले काठमाडौं उपत्यका भित्र र बाहिर नवदुर्गा मूर्तिहरू स्थापना गरेर नवदुर्गाको पून. पूजा उपासना परम्परा चलाएको मानिन्छ।

मध्यकालतिर नवदुर्गा नाच भक्तपुर, कीर्तिपुर, ठिमी, पाटन, काठमाडौं, नुवाकोटतिर नचाइन्थ्यो भन्ने धैरै प्रसड़्ररू आउँछ् । यी मध्ये भक्तपुरको नवदुर्गानाच आजसम्म पनि सवैभन्दा प्रशिद्ध छ। नवदुर्गा संस्कृतिको आदिस्थान वा मूलथलोको रूपमा भक्तपुर नै स्थापित छ। भक्तपुरमा नवदुर्गानाचको शुरुवात सम्वन्धि यस्तो किंवदन्ती रहेको छ- एक समय नवदुर्गागण उग्र र आक्रोसित भै सामुन्ने परेको अभक्ष जीव सुँगुरको समेत भोगवलि लिदै हिंडे, पछि यी कुद्ध भएका देवीहरूलाई शान्त पार्ने उपाय पनि देवीहरूले नै वताई दिए; जसअनुसार नवदुर्गागण समावेश भएको एउटा तात्त्रिक नाच वनमाला जातिलाई सिकाई दुनियाका अगाडि देखाईने भईयो र यसको निमित्त मोहनी (कालो टीका) साधना गर्नु पर्ने भयो। उक्त मोहनी लगाएपछि मुखुन्डोधारी देव प्रतिनिधिहरूको शरीरमा नवदुर्गागणले प्रवेश गरी शान्त स्वरूपमा साक्षात दर्शन दिने भए र नवदुर्गानाच मानिसमा नै देवता चढाई नविन पद्दतिको प्रयोगसंगै सिद्दहरूले शुरुवात गरे, यी सवै कार्य सोमराज नाम गरेका सिद्ध ब्राम्हणको नेतृत्वमा भएको मानिन्छ (श्रेष्ठ, वि.सं.२०७४ पृ. ७१)। मध्यकालमा काठमाडौं उपत्यकामा दुर्गापूजालाई 'मोहनी' चाडको रूपमा मनाइन्थ्यो। यस समयमा वली चढाएर वा दुर्गा चण्डीपाठ, दुर्गा सप्तसतीको पाठ गरेर दुर्गा उपासना गरिन्थ्यो। मेरी स्लसर अनुसार 'नवदुर्गाहरू शहरका दैवीय सुरक्षाका निम्ति निर्माण गरिएका सुरक्षाघेरा भित्र पर्ने पर्खालहरूमा स्थापित स-साना देवदेवी र आत्माहरूको र सम्पूर्ण उपत्यकाको सुरक्षा घेरासंग सम्बन्धित ठूला ठूला देवदेवीहरू वीच मध्यस्थकर्ता मानिन्छन्। यस्तो सुरक्षा घेराभित्र नवदुर्गाका सहयोगी मानिएका गणेश, भैरव, दशमहाविद्या आदिको मन्दिर वनाएपछि त्यस बाहिरको अर्को सुरक्षा घेरामा नवदुर्गाहरूको मन्दिर स्थापना गर्ने परम्परा पाइन्छ। दुर्गा पीठहरूमा रहस्यमय चित्रहरूको रूपमा यन्त्र, योगिनी चक, मण्डल र दिगमण्डलहरू बनाउने परम्परा पनि रहेको पाइन्छ। 
दुर्गाको महिषासुर-मर्दिनी (महालक्ष्मी) स्वरूप : देवीका हजारौं स्वरूप भएपनि मूल देवी शिवकै शक्तिस्वरूपा एकै नै हुन्। आफ्नो दायित्व, आवश्यकता, अवस्था, स्थिति हेरेर यिनले विभिन्न रूप लिएको हुन्छ, । यसै अनुरूप महिषासुरमर्दिनी पनि एक हुन्। उनको यो स्वरूपलाई पनि नवदुर्गारूपमा लिईन्छ। नेपालमा दुर्गाका विविध स्वरूपहरू मध्ये महिषासुरमर्दिनी स्वरूप ज्यादा प्रसिद्ध छ। यहाँ प्रष्टरूपमा महिषासुरमर्दिनी स्वरूपको अस्तित्व ईश्वीको दोश्रो तेश्रो शताव्दी देखि प्राप्त भएको प्रमाण यो कालको मूर्तिहरू वाट पाइन्छ (श्रेष्ठ, वि.सं.२०७४ पृ. ६९)। हाँडीगाउँ धन गणेश मन्दिर भित्र रहेको महिषासुरमर्दिनीको मूर्ति तेश्रो शताव्दी हो भनी लैनसिंह बाङेदेले उल्लेख गरेका छन् (बाङुदेल, १९६२ पृ. ३४)। त्यसैगरी चाँगुनरायण मन्दिर प्राङुणमा रहेको छिन्नमस्ता मन्दिर भित्रको महिषासुरमर्दिनीको मूर्तिलाई उपत्यकामा प्राप्त प्रारम्भिक कालका मातृकाका मूर्तिहरू मध्ये एक मानिएको छ (खनाल, वि.सं. २०४२ पृ. १६७-६६)। देवीले महिषासुर नामक दैत्यको वध गरेको स्वरूपलाई महिषासुरमर्दिनी भनिन्छ। देवी महात्म्य, मत्स्यपुराण र रूपमण्डनमा देवीको यो रूपलाई कात्यायनी भनिएको छ। पुराणमा यो रूपको अनेक कथाहरू पाइन्छन्। विष्णुधर्मोत्तर पुराणमा देवीको यो रूपलाई चण्डी भनिएको छ (श्रीवास्तव, १९९० पृ. १३३)। यो ग्रन्थ अनुसार यिनी तीन नेत्र, स्वर्ण वर्ण, युवती स्वरूप, कोधित मुद्रा र सिंहमा आरुढ हुन्छिन् । उनको पातलो कम्मर, बिशाल नेत्र, सुन्दर सुपुष्ट स्तन, सुन्दर गर्दन, बीसबाहु भएकी र वाहुहरूमा दाहिने तर्फ शूल, तलवार, शंप, चक्र, वाण, शक्ति, वज्र, डमरु, छत्र, अभयमुद्रा र वायाँतर्फ नागपाश, खेटक, कुठार, अंकुश, धनुष, घण्टा, ध्वज, गदा, दर्पण तथा मुद्गल रहन्छ (उही)। देवीको छेउमा दैत्यको काटिएको महिष भाग हुन्छ र वास्तविक दैत्य उसको गर्दनबाट निक्लिंदै गरेको देखाईन्छ। नागपाशले वाँधिएको दैत्यले २ हातमा ढाल र तलवार लिएको हुन्छ। देवीले त्रिशूलले उसको गर्दनमा रोपेको, सिंहले टोकेको उसको गर्दनबाट रक्तधारा बगिरहेको हुन्छ (उही)। नेपाल र भारतका अधिकांश महिषासुरमार्दिनीका मूर्तिहरू यही स्वरूपका रहेका छन्।

\section{२. निष्कर्ष}

शाक्तथर्म मानव सभ्यतासंगै शुरुवात भएको पाइन्छ। देवीका हजारौं स्वरूप भएपनि मूल देवी शिवकै शक्तिस्वरूपा एकै नै हुन्। आफ्नो दायित्व, आवश्यकता, अवस्था, स्थिति हेरेर यिनले विभिन्न रूप लिएको हुन्छ। नवदुर्गा समूह त्यसैको परिणाम हो। नेपालमा पाईएका दुर्गाका विविध स्वरूपका मूर्तिहरू मध्ये महिषासुरमर्दिनी स्वरूप ज्यादा प्रसिद्ध छ। लगभग ईश्वीको प्रारम्भ देखि नै प्राप्त दुर्गाको यो स्वरूप लगाताररूपमा प्रशिद्ध रहेको छ। मातृमतको उत्पत्ति र विकासक्रमको चरमोत्कर्षकालमा नवदुर्गा सस्कृतिको अविर्भाव हुनपुगेको हो। नवदुर्गामा नौवटी देवीहरूको समूह वाहेक एकिकृतरूपमा एउटै महिषासुरमार्दिनी दुर्गा भवानीलाई मानिन्छ। तन्त्रप्रधान नवदुर्गा गणको मूल चरित्र एवं गुप्तरूप यिनै महिषासुरमर्दिनी दुर्गा भवानी हुन्। मानव देहमा न्यास गरी देवता चढाउने नूतन पद्धतिको प्रयोग सिद्धहरूले गरे मुताविक नवदुर्गा गणलाई पनि देहधारी मानिसमा प्रवेश गराई जात्रा, पूजागर्ने परम्परा पनि रहेको छ। जीवित देवताको रूपमा नवदुर्गागण भक्तपुरमा ज्यादा प्रसिद्ध छन् ।

\section{सन्दर्भ सामग्री}

उपाध्याय भट्ट, विद्यानाथ. (वि.सं. २०७४). नेपालमा शाक्तर्धर्म, दर्शनको परम्परा, शाक्त-उपासना पत्र. पशुपतिक्षेत्र विकाश कोषमा प्रस्तुत अप्रकाशित शोधपत्र । 
एलेन, माइकल. (१९७४). द कल्ट अफ कुमारी भर्जिन वर्सिप ईन नेपाल. काठमाडौं : ईन्स्टिच्युट अफ नेपाल एण्ड एशियन स्टडिज, त्रि.वि.वि ।

खनाल, मोहनप्रशाद. (वि.सं. २०४२). नेपाली कला. ललितपुर : साका प्रकाशन ।

ज. व.रा., धनशम्शेर. (वि.सं. २०३०). मातृकाक्षररहस्यम. काठमाडौं : नेपाल राजकीय प्रज्ञा प्रतिष्ठान ।

जोशी, हरिराम. (वि.सं. २०७०). प्रदिप अभिनव संस्कृति विश्वकोष. भक्तपुरः वर्कर्स पब्लिकेसन्स् ।

पाण्डेय, राजवली. (१९६६). हिन्दु धर्म कोश, लखनउ : उत्तर प्रदेश हिन्दी संस्थान ।

प्रिस्टन, जेम्स.जे.(१९५०). कल्ट अफ द गडेसेस, न्यु डिल्ली : विकाश पव्लिसिङ हाउस ।

पोखरेल, निर्मला. (वि.सं. २०७७). "देवी: सृष्टि, पालन र संहारकर्ता" कान्तिपुर, २०७७-७-२।

वसिष्ठ, गौरिशंकर (टिप्पणीकार). (वि.सं.२०प७७). श्री दुर्गाशप्तशती (चण्डी). वाराणसी : श्री दुर्गा साहित्य भण्डार ।

वज्राचार्य, धनवज्र. (वि.सं. २०४३). लिच्छवि कालका अभिलेख. काठमाडौं : नेपाल र एशियाली अनुसन्धान केन्द्र। बाड्रदेल, लैनसिंह. (१९६२). द अर्लि स्क्लच्चर अफ नेपाल. काठमाडौं : बिकाश पब्लिसिड हाउस ।

श्रीवास्तव, बृजभूषण. (१९६०) प्राचीन भारतीय प्रतिमा विज्ञान एवं मूर्ति-कला. वाराणसी : विश्वविद्यालय प्रकाशन ।

श्रेष्ठ, पुरुषोत्तमलोचन. (वि. सं. २०७४). “भक्तपुरको नवदुर्गा गण”. मधुपर्क- अमूर्त संस्कृति विशेषाङ्क वर्ष पू०, अड्क १: पूर्णाङ्क पू७६. गोरखापत्र संस्थान । 